\title{
Unilateral Economic Sanctions
}

\author{
Dr. Abdullah Al- Khseilat, Middle East University Jordan \\ Dr. Ayman Yousif Al - refou, Middle East University Jordan \\ Dr. Salem mekhled Salem AL-hmalan Jordan
}

\begin{abstract}
After the failure of the League of Nations in dealing with the Second World War, the United Nations was keen not to repeat the tragedies of war, targeting the maintenance of international peace and security, and using peaceful means to resolve international conflicts in accordance with the principles of justice and international law.In order to achieve its previous goals, this organization possessed a set of guarantees and penalties that its charter included. However, the United Nations was not the only organization that used these sanctions. Rather, countries resorted unilaterally to using these sanctions to achieve their goals and interests. As the second half of the twentieth century witnessed a great expansion in the countries 'resort to using unilateral economic sanctions, whether this expansion is related to the intensity and breadth of imposing such sanctions on the level of international relations or related to the multiplicity of their forms and levels, as well as the development of their tools and policies-The major countries, led by the United States of America, are not reluctant to use their enormous economic power and capabilities and to take the sanctions that they deem appropriate at a time when they find it appropriate as one of the means of pressure and extending hegemony against other countries, with the intent to compel the target country to comply with its orders and change its policy and attitudes in a manner that is compatible with the interests of the country imposing such countries. However, this violates the target country's sovereignty, independence and principles of its economic life.Therefore, unilateral economic sanctions represent a clear violation of the principles of international law and its peremptory norms, especially those rules that prohibit members of the international community from resorting to force, or merely threatening to use it on the level of international mutual relations among them, as well as a violation of the rules that affirm the sovereignty of countries and the inadmissibility of intervention in their internal affairs or in the area reserved for those countries.Unilateral economic sanctions usually carry any character other than military ones, as they may include economic embargoes, economic boycotts, blockades and seizures of property, restricting the activity of foreigners with the nationals of the target country through measures and restricting the trade of the target country, as well as other similar measures. Such sanctions may amount to unilateral economic intervention.
\end{abstract}

Keywords: Unilateral economic sanctions- economic embargoes- economic boycotts- blockade- seizureunilateral intervention- international peace and security

DOI: $10.7176 / \mathrm{JLPG} / 94-16$

Publication date: February $29^{\text {th }} 2020$

\section{INTRODUCTION}

The international community introduced the first integrated system of sanctions during the League of Nations era, which was established after the end of the First World War, with the aim of finding solutions to international conflicts and preventing the aggravation of problems that lead to warfare among countries.

As the League of Nations experience was the first experience in establishing an organization for the international community, in response to the necessity of cooperation among countries, which was spelled out by the multiplicity and development of international relations and their breadth, the inability of a single country to meet the requirements of these changes and the developments witnessed by the international community. With the emergence of the League of Nations, countries were able to meet a large number of their needs in international integration, and as a result, a new international law emerged to keep pace with these developments.

The emergence of the League of Nations was linked to the system of collective security, which used the League as a means through which this system can be applied in practice. Among the most important rules included in the system of collective security are the principle of the illegality of war, the peaceful settlement of international disputes, and to ensure the independence of members of the organization, in addition to a system of sanctions.

However, the reality imposed by the Second World War showed the failure of the League of Nations in dealing with this war, so the United Nations was keen not to repeat the tragedies of war, targeting the maintenance of international peace and security, and using peaceful means to resolve international conflicts in accordance with the principles of justice and international law.

In order to achieve its previous goals, this organization possessed a set of guarantees and penalties that its charter included.

However, the United Nations was not the only organization that used these sanctions. Rather, countries resorted unilaterally to using these sanctions to achieve their goals and interests. As the second half of the twentieth century witnessed a great expansion in the countries 'resort to using unilateral economic sanctions, whether this 
expansion is related to the intensity and breadth of imposing such sanctions on the level of international relations or related to the multiplicity of their forms and levels, as well as the development of their tools and policies-

Although proper international action requires economic sanctions imposed by the United Nations, being the international political institution specifically mandated to maintain international peace and security against a country as a result of its violation of international law as well as its deviation from its standards, in an attempt to compel the target country intended by these sanctions to return to the accepted patterns of international behavior. However, the major countries, led by the United States of America, are not reluctant to use their enormous economic power and capabilities and to take the sanctions that they deem appropriate at a time when they find it appropriate as one of the means of pressure and extending hegemony against other countries, with the intent to compel the target country to comply with its orders and change its policy and attitudes in a manner that is compatible with the interests of the country imposing such countries. However, this violates the target country's sovereignty, independence and principles of its economic life.

Perhaps there are many examples of the major powers' use of power politics in international relations, and the imposition of sanctions that depend on economic tools and means unilaterally against other countries, with a view to influencing its will and obliging it to make concessions that serve the interests of the country imposing sanctions, such as the blockade imposed by the United States of America on Cuba in 1960; economic sanctions imposed by France on Tunisia in 1964, claiming that Tunisia confiscated the property of foreigners in it; American economic sanctions imposed on Libya in 1978, being accused of supporting terrorism and on Iraq in 1980 on the pretext of supporting terrorism, in addition to banning import and export on Nicaragua and breaking the trade and navigation agreement with it in 1985, and US economic sanctions against Sudan in 1989 because of the civil war and its violation of human rights, in addition to accusing him of supporting terrorism.

\section{Research importance:}

The spread of the phenomenon of countries resorting to imposing sanctions of an economic nature unilaterally without authorization or supervision by the United Nations Organization, is a very dangerous phenomenon in view of the chaos and instability that it creates on the level of mutual international relations and collective security, in addition to the devastating consequences it might lead to concerning the national economy of the victim country, in addition to the effects and repercussions of these sanctions may reach the point of overthrowing the existing regime of government, igniting civil wars, or exacerbating local crises. Perhaps this is what necessarily leads to study these sanctions, given their seriousness, the magnitude of their results and their impact on the existence, interests and sovereignty of countries.

\section{Research problem:}

The research raises a basic question regarding what are the unilateral international economic sanctions. This question is divided into the following questions:

1. What is the definition and legal basis of international unilateral sanctions?

2. What are the types of unilateral economic sanctions?

\section{Research objectives:}

One of the aims of this study is to answer the previous questions, as well as to define the concept of international (unilateral) economic sanctions used by the major powers, especially in an unilateral way, for the purposes of pressure and coercion directed against a sovereign country or a group of countries, with the intention of controlling them, dictating conditions, and imposing plans to achieve the political, economic, social, and military goals that the country imposing sanctions wishes to achieve.

\section{Research plan:}

The current research is divided according to the following plan:

First topic: The concept of unilateral economic sanctions

Second topic: Types of unilateral economic sanctions

\section{First topic:}

\subsection{The concept of unilateral economic sanctions}

Unilateral economic sanctions are considered within international economic sanctions, which are distinguished by their imposition by one country against another country or a group of countries, individually and outside the framework of the international organization. Therefore,Such unilateral sanctions differed from international economic sanctions, whether in terms of the legal basis of each of them or in terms of some types and forms of economic sanctions, but they are similar in that they have an economic impact or character.

\subsubsection{First section:}

\section{Definition of unilateral economic sanctions}

Resorting to the use of the weapon of unilateral economic sanctions is not new in international relations, although 
it is noted that in recent years there has been an expansion in the scope of some countries using their economic tools and means against a sovereign country or group of countries. There has also been a significant increase in the number of cases in which these measures were resorted to, in order to reach certain goals, whether economic, political, social or military, that would serve the interests of the country imposing sanctions.

These sanctions involve a country's use of its economic means, tools and capabilities against another country in order to influence it and reach certain goals and interests that are disconnected from the goals of international organizations. 1

Therefore, unilateral international economic sanctions represent a threat to international economic relations and a threat to the principles of international law. 2

The countries that use these sanctions aim to achieve their goals by forcing the concerned country to make concessions or change its behavior or its internal or foreign policy. Some countries, particularly the United States of America, prefer to resort to such sanctions in implementing their foreign policy.3

Unilateral economic sanctions can be defined as: Those punitive measures of an economic nature, imposed by one country against another or a group of countries, with the intention of pressuring them politically, without the latter being able to defend its right to natural economic treatment). 4

The Institute of International Law has defined unilateral sanctions as: (the procedures considered as a deviation from the ordinary rules of international law, to be decided and taken by a country in response to the acts committed by another country, which resulted in harm thereto, and such procedures aim to induce the state, by putting pressure on it and harming it, to return to legality).

Thus, such sanctions are considered a means of achieving the foreign policy of some countries and affecting the internal economic elements of the target country through such measures.

In current international law, economic measures of a coercive nature are sometimes called unilateral economic sanctions, which are adopted unilaterally by countries within the scope of self-help or the fulfillment of the right by oneself, in response to another country violating the law without the use of armed force, so that this act violates the rights of this country or its legal interests in order to give such sanctions a legal character on the one hand and evade international responsibility by doing them on the other hand.5

A section of jurisprudence described those sanctions as expressing "negotiation" between two countries, given that the country that imposed these sanctions put pressure on another country to force it to make concessions or stop behavior it had taken in its policy. 6

All these attempts are due to the legality of the international economic sanction (imposed in the framework of an international organization), and the illegality of unilateral economic sanctions.

It is worth noting that there is another form of unilateral economic sanctions applied in federal countries (composite countries) such as the United States of America, so that one of these states imposes unilateral sanctions, without referring to the federal central authority, such as the sanctions imposed by the state of New York on Cuba, China, Kuwait, Morocco, North Korea, Sudan and Pakistan, under the pretext that these countries have violated the rights of religious minorities, as well as what the states of Massachusetts and Rhode Island imposed on Indonesia in the issue of East Timor.7

There is no doubt that this image will put the federal country in a state of confusion, and divide its political decision, especially that it may be used for electoral purposes in some states, in addition to the unconstitutionality resulting from the use of those sanctions in violation of the federal constitution. Article 6 of the US Constitution states: "This Constitution, and the Laws of the United States which shall be made in Pursuance thereof; and all Treaties made, or which shall be made, under the Authority of the United States, shall be the supreme Law of the Land; and the Judges in every State shall be bound thereby; any Thing in the Constitution or Laws of any State to the Contrary notwithstanding" This was confirmed by the Supreme Court in a ruling in which it decided that the law issued by the state of Pennsylvania was unconstitutional in which the latter imposed restrictive rules for registering foreigners, in a way that exceeded federal law.8

A part of American jurisprudence has gone so far as to point out that the reason for not showing the defect of constitutionality against the sanctions decision is the companies' fear that they will appear in a supportive aspect

(1) Dr. Khawla Yusuf, International economic sanctions adopted by the Security Council, Al-Halabi Human Rights Publications, Beirut, 2012, p. 134.

(2) Dr. Imad Habib, International Economic Law, Nineveh Studies, Damascus, 2001, p. 116.

(3) Mary Helen Labet, Economic Struggle in International Relations, translated by Hassan Haidar, Aweidat Publications, Beirut, 1996, p. 13.

(4) Dr. Ibrahim Nowar, Blockade and Development, Al-Ahram Center for Political and Strategic Studies, Cairo, 1997 , p. 4.

(5) Dr. Yasser Al-Huwaish, Principle of Non-Interference and Global Trade Agreements, PhD thesis, Ain Shams University, Egypt, $2001,198$.

(6) Lucie spanihelova how states decide between unilateral and multilateral senctions, research published by deparment of political sience sunny, binghamtion 'ISA annual conference san diego, CA, 22-26 march, 2006, p11.

( 7 ) Robert p.Q quinn, auser's guide to economic santionsm, the heritage foundation, 1997 heritage foundation website

"http//www.heritage.org/research/national security", p12.

(8) See Article 6/2 of the American Constitution. 
of such sanctions, especially if they relate to human rights violations. 1

From the foregoing, we conclude that unilateral economic sanctions are consistent with international economic sanctions (taken by an international organization) of an economic nature, but differ from them in the body that imposes them (or the competent authority that shall sign them). Whereas the international organization is the framework of imposing international economic sanctions, whether they are imposed by the organization's bodies or countries are mandated to implement them, therefore countries shall then impose unilateral economic sanctions.

Consequently, we conclude from the above that the characteristics of unilateral economic sanctions are that they are imposed by a country unilaterally (that is, outside the framework of the international organization), against a country in order to force it to take action or refrain from it.

\subsubsection{Second section:}

\section{The legal basis of unilateral economic sanctions}

If the Charter of the International Organization is the legal basis of imposing international economic sanctions, then the legal basis of unilateral economic sanctions, in view that a country unilaterally imposes them outside the charters of international organizations, raises a problem.

This necessitates examining this legal basis through:

First: Illegality of unilateral economic sanctions.

Second: Legality of unilateral economic sanctions.

\subsubsection{First: Illegality of unilateral economic sanctions}

Unilateral economic sanctions represent a clear violation of the principles of international law and its peremptory norms, especially those rules that prohibit members of the international community from resorting to force, or merely threatening to use it on the level of international mutual relations among them, as well as a violation of the rules that affirm the sovereignty of countries and the inadmissibility of intervention in their internal affairs or in the area reserved for those countries.

Therefore, we will discuss the illegality of unilateral economic sanctions by studying the following two principles:

1. Violation of unilateral economic sanctions to the principle of prohibiting the use of force in international relations:

The principle of the prohibition of the use of force in international relations is considered the cornerstone of the international legal system, especially the United Nations system, and this principle has brought about a fundamental change in the rules of traditional international law, which allowed countries to achieve their purposes through violence, and thus resolve their international disputes and differences using force or threatening to use it.2

The United Nations Charter, in many subjects, stipulated the prevention of the use of force in international relations. The preamble prohibited the use of force except in the common interest of all members of the international community. 3

Article 2 of the Charter, in its fourth paragraph, discussed the countries' duty of refraining from using force, or threatening to use force against the territorial integrity or political independence of any country, or in any manner inconsistent with the purposes of the United Nations. 4

All of this is in order to achieve the goals for which the United Nations was established, and which are all in the category of maintaining international peace and security, which are impossible to reach except in the absence of the use of force in international relations.

The principle of the prohibition of the use of force contained in Article 2/4 of the Charter differs from the provision that was contained during the era of the League, as the latter finds it enough to criminalize the use of war while disregarding other forms of the use of force. It also differs from the Brian Kellogg Charter (Paris Charter) of 1928, which includes a general prohibition on entering a war, but does not provide for a general prohibition of the use of force. ${ }^{5}$

While Article 2/4 of the Charter obliges all members of the international community not to resort to force as a means to achieve national policy, and therefore the principle of prohibition stipulated in the League's era, as well as the Brian Kellogg Charter, was limited and incomplete, while, under the Charter of the United Nations, it has become almost general and comprehensive for all images and cases of the use of force, or the threat to use it in international relations. 6

In this context, a part of the jurists sees that the principle of preventing the use of force contained in the Charter is much broader than the prevention of war contained in the era of the League, or the Brian Kellogg Charter

(1) Robert P.O'quinn, Auser's guide to economic op.cit, p14.

(2) Dr. Abdullah Muhammad Al-Ayoun, Collective Security System in the Modern International Organization, Dar Al-Bashir and Distribution, Amman, Jordan, 1985, p. 82

(3) Dr. Abdullah Muhammad Al-Ayoun, Collective Security System in the Modern International Organization, Ibid, p. 83.

(4) Dr. Muhammad Al-Majzoub, Public International Law, Al-Halabi Human Rights Publications, Beirut, Lebanon, 2002 , p. 311.

(5) Dr. Ibrahim Al-Anani, Public International Law, Dar Al-Fikr Al-Arabi, Cairo, 1984, p. 586.

(6) Dr. Abdullah Mohammed Al-Oyoun, ibid, pages 82 -83. 
(the Paris Charter), so the use of force contained in the Charter is a general ban, in addition that the phrase of "use of force or the threat to use it" is more comprehensive than "war."1

The text of Article 2/4 sparked a wide jurisprudence and international dispute over the interpretation of the meaning of the term force, as The Charter of the United Nations did not specify it.

In lights of the international divisions in regard of the term "force", western capitalist countries confined this concept to military force only, arguing that the preparatory works for the aforementioned text proves that what is meant by the term "force" is only military or armed force.(2)

As for the juristic disagreement, we find that the jurists of international law has been divided into two categories, where some jurists consider that Article 2/4 embargo only the use of armed force or the threat to use it.This understood from the logical interpretation of the text, likewise, though the force is not described as armed, the context of the text excludes the intention of economic pressure. On the other side the preparatory works for the aforementioned text prove that the meaning intended by the term force refer to only armed force (3). Another section of jurisprudence has also confirmed that, as it went so far as to demonstrate from the Nuremberg trials and discussions that had taken place on about the definition of aggression and the international community's adoption of the definition of aggression in 1974 that it went to restrict the interpretation of "force" to armed or military force only.(4)

Another side has stated that the term force is that the term force meant the armed force based on the preamble to the Charter, which states: «To ensure that we accept certain principles and set the necessary plans for them, that we do not use armed force in a way that is not in the common interest» the framers of the Charter indicated the use armed force only and no other forms of force, such as economic and political pressures. (5)

On the other hand, a section of the jurisprudence stated that the concept of the embargo contained in the Charter was general and absolute, so that it could meant not only to armed force, but also extend to include all economic pressures and interventions, which enter into unilateral economic sanctions within its framework.(6)

From the foregoing, we conclude that it is necessary to work to expand the rule of the embargo of the use of force at the level of international relations in order to maintain international peace and security, by preventing states from using unarmed force by resorting to unilateral economic pressures and sanctions.

Therefore, these sanctions are an expression of the politics of power and domination in international relations, which is inconsistent with the provisions and principles of contemporary international law and the decisions of international legitimacy.

2. Sanctions violation of the principle of sovereignty of nations and non-intervention in internal affairs: To define the principle of non-intervention, the concept of intervention itself must be also defined, which may take shape in coercion by using armed force, or take other descriptions, although it does not involve the use of armed force, such as economic power, for example.(7)

A jurisprudential dispute arose regarding the interpretation of the intended intervention contained in the Charter, which was decided in Article 2/7 to be: «Nothing in this Charter shall permit the United Nations to intervene in matters that are at the integral to the internal authority of a country, and there is nothing in it that requires members to present such matters to be resolved by virtue of this Charter».

This disagreement has disputed into three directions. Supporters of the first direction, among them the jurist "Grotius", limit the intervention to violent behavior, and they consider it as a war. Therefore, according to this direction, there is no difference between intervention and war, meaning that traditional jurisprudence focuses on intervention by armed force only, which would compromise the integrity and independence of the country.(8)

As for the second direction, its supporters, including jurist "Vattel", see that the intervention is not limited to the use of armed or military force or the threat to use it, but rather includes any act that affects the personality, sovereignty, and independence of the country. All actions that affect the sovereignty and independence of the country are illegal, whether or not these actions are based on the use of armed force. (9)

Whereas the third direction is based on the convenience and reconciliation of the previous two directions, and consider the intervention be achieved regardless of the method in which the intervention was used, provided that the intention of the intervention is available to the intervention country, Therefore, according to this direction, the

(1) Dr. Abdullah Mohammed Al-Oyoun, ibid, page 82

(2) Dr. Muhammad Al-Saeed Al-Dakkak, The International Order, al-Dar al-Jamieia lil-Tibaah wa-al-Nashr, Alexandria, n.d., page 231.

(3) Dr. Muhammad Al-Saeed Al-Dakkak, ibid. page 232.

(4) Dr. Abdul Qadir Al-Qahwaji, Al-Qanoon Al-Janaie, Manshurat Alhalabi Alhuquqia, Beirut, Lebanon, 2001, page 20.

(5) Dr. Abdullah Mohammed Al-Oyoun, ibid, page 85.

(6) Dr. Ibrahim Darajy, Ibid, page.117 \& Dr. Pokra Idris, Mbdaa' Al-tadakhol feh Al-qanon Al-dawli Al-mo'aser, Al Moasasa Al Watania lil Kitab, Algeria, 1990 page.123.\& Dr. Abdul Salam Saleh Arafa, Al Monazamat Al Duwaliya wa Al'iiqlimia, Al-Dar Al-Jamahiria lil Nashr, Libya, 1999, P.114.

(7) Shaw (Martin), the global state and the politics of intervention the center for the study of global governance London school of economics, 1994 discussion p.13.

(8) Dr. Mohamed Mostafa Younes, The General Theory of Non-Interference in County Affairs, a Doctrinal and Applied Study in light of the Principles of Contemporary International Law, Doctoral thesis, Cairo University, 1985, P.23.

(9) Dr. Muhammad Yunus, Ibid, p. 26. 
concept of intervention is not limited to the intervention is not limited to the use of armed or military force or the threat to use it. However, it does not extend it to any statement or action related to the affairs of another country. Rather, it requires that the intervening country intent by its intervention to impose its will on the targeted country through another method. (1)

In any case, some has defined intervention as: (A country preying into the affairs of another one in an authoritarian manner with the intention of maintaining or changing the current conditions, and such intervention may take place with or without the right).(2)

Others has defined it as:(Actual pressure exerted by one or several countries on another country with the intent to compel it to take action or refrain from work or to refrain from arbitrary actions that the country brings against the private interests of foreign countries).(3)

Another side define it as:(Every exorbitant intended act undertaken by an international legal person in order to deny the sovereignty and independenceof the concerned country).(4)

Based on these definitions, we can conclude that intervention is pressure imposed by a person of international law against another country, with the intent to force it to take a certain action or refrain from it.

It is worth mentioning that this pressure or behavior may be dependent on armed force, or dependent on economic sanctions (such as cutting economic and trade relations) from one side.(5)

On the other hand, this pressure is exerted by a person of international law persons, such as countries and international organizations, and countries are the ones that practice the intervention more clearly and more than organizations, where its intervention may be considered legitimate if it is an application of the organization's decision, or it may be unlawful if it does not rely on such a decision, but rather its intervention was a policy followed by the country intervening in its international relations.(6)

International organizations may also intervene - despite the express prohibition in the Charter - in accordance with the system of collective security, where Article 2/7 of the United Nations Charter stating that: "The principle of non-intervention is without prejudice to the application of the repression measures mentioned in Chapter Seven."(7)

On the other hand, the countries are considered the targets of intervention from among the subject of international law, while international organizations inconceivable intervention in their affairs, as international jurisprudence considers what intervening organizations are subjected to as pressures that do not rise to the level of intervention, It is conceivable that these pressures will occur when violating of contractual obligations, as if the countries that exert pressure are refraining from paying their financial obligations in order to push the organization to do or follow a specific behavior.(8)

In any case, whoever intervenes (whether it is a country or an international organization), the objective of that is to the will of the country imposing intervention (or the organization) on the targeted country, and intervention in their internal affairs and foreign policy in order to push it to adopt a specific behavior or refrain from it.(9)

In other words, the imposing country aims from intervention to adopt the concernedcountry for positive behavior, such as imposing it to vote alongside a decision, or to facilitate the use of their territories by foreign forces in order to carry out military actions against a third country, or forcing it to follow a specific economic policy in a manner compatible with the interventionistpolicy of the intervening country, and behavior shall be negative, such as asking it to abstain from a specific policy in a case.(10)

From the above, we conclude that the substance of intervention is to enforce the implementation of works, certain acts or refrain from doing any act, whether it is imposed by an international organization or by a country unilaterally, In such case, that is, when a country intervenes in the affairs of another one, its unilateral intervention is illegal, Because this intervention took place outside the framework of an international organization and its decisions. If the intervention of the country was by the decision of that organization, its intervention would be in implementation of the resolution of the international organization and an expression of the will of the international community, therefore, would be legitimate. As the international organization allows intervening countries to impose its rights (which are violated by other country) by only one side. As if, the international organization

(1) Lauterpacht (h), the international protection of human rights, Rcadi, 1947, tome 70, p19.

\& Dr. Muhammad Yunus, Ibid, p. 29

(2) Dr. Mohammed Talaat al-Ghunaimi, Mediator in the Peace Law, Munsha'at Al Maearif, Alexandria, P.292.

(3) Dr. Abdel Wahad El Far, The Nature of the International Economic Base under the Existing International System, Dar al-Nahdah alArabiyah, 1985, P. 32.

(4) Dr. Muhammad Yunus, Ibid, p. 32

(5) Dr. Pokra Idris, Mbdaa' Al-tadakhol feh Al-qanon Al-dawli Al-mo'aser, Al Moasasa Al Watania lil Kitab, Algeria, 1990 page.21.

(6) Dr. Muhammad Yunus, Ibid, p. 150

(7) Dr. Abdul-Aziz Sarhan, The New International Order and International Legitimacy and Its Impact on the Arab World, A Study in the Light of the General Theory of International Organizations, Cairo, Dar Al-Nahda Al-Arabia, 1993, p. 6.

(8) Dr. Mohamed Bedjaoui, for a New International Economic Order, UNESCO and the National Publishing and Distribution Company, Algeria, 1980, pp. 198-199.

(9) Dr. Mohamed Bedjaoui, Ibid, p. 199

(10) Dr. Mohamed Bedjaoui, Ibid, p. 200 
entrusted the intervention to one of its international bodies alone (as Security Council). The unilateral intervention by the country in this case is illegal and has no international legal basis.

In addition to the existence of a rule of customary international law that prohibits the country from intervening in the internal affairs of another country, and it was confirmed in many decisions, such as Resolution / 2625 / issued by the General Assembly on 10/24/1970 under the title (Declaration of Principles of International Law Relating to Friendly Relationships Between Countries according to the United Nations Charter). (1)

As for the principle of country sovereignty - as a principle that makes unilateral economic sanctions illegal, it is the cornerstone of the modern legal system that exists between countries.

As the sovereignty of the country over its territory and its nationals, its authority in its territory and its relations with its nationals, is one of the issues related to the domestic jurisdiction of States or the area reserved for countries, which shall not be intervened with by any country.(2)

Another aspect of jurisprudence states that the sovereignty of a country is tied to certain constraints where any forms of arbitrariness, especially the sovereignty manifestations that are not allowed to be practiced by a country in a way that constitute an intervention in the country affairs and a violation to its sovereignty. NoninterventionPrinciple is a necessity to the principle of equality of States; this equality requires the respect of country affairs and sovereignty of each other. Thus, the sovereignty of a countryis tied to the sovereignty of other states pursuant to the principle of principle of sovereignty and equality. (3)

By extrapolating the historical development of international law, we find that it did not abolishing sovereignty and increasing intervention in internal affairs, but rather the opposite. Sovereignty represents a fence in which protecting developing countries themselves from the intervention of major powers with a view to impose their policies against these countries, and therefore shall stand against it because its intervention in the internal affairs of countries is considered a blatant intervention that against the established rules in this regard.(4)

Based on above, it can be said that the imposing unilateral economic sanctions by the major powers - outside the approval of the international organization - is a clear violation and flagrant violation of the principle of country sovereignty, which prevents any country from imposing obligations against another sovereign state, because this constitutes unlawful intervention in the affairs of the concernedcountry in order to influence its will and its coercion to comply with the demands and orders referred to it by the major powers, which threatens international relations in general and economic in particular.

In addition, unilateral sanctions that affect the other international principles and rules contained in the preamble and provisions to the Charter, and international action have been established with a view to achieving international security and stability in their broadest sense, Such as the principle related to the peaceful settlement of international disputes in a manner in which international peace and security, as well as States vulnerable, and principles relating to the development of friendly relations and the development of peaceful coexistence between countries.(5)

\subsubsection{Second: legitimacy of unilateral economic sanctions:}

The legitimacy of economic sanctions comes from the fact that they depend on economic means adopted individually or collectively by governments in the framework of an international or regional organization, against a sovereign state or countries that overstepped of their international obligations, in an attempt to compel the country to adhere to acceptable patterns of international behavior.(6)

Consequently, the legitimate economic sanction is the punitive that an international organization takes against a country that violates the principles or norms of international law with the intent to compel her to respect its rules.

In return, if a country proceeded to pursue punitive sanctions that is economical in nature against sovereign country for violating or being accused of violating the international law, without supervision of the international organization responsible for the maintenance of international peace and security - that is, the United Nations -, It thus violates the principle of the sovereignty and economic independence of this country, and threatens its economicstatus ${ }^{(7)}$. Therefore, its behavior is unlawful, and it can constitute economic aggression. Whereas the economic pressure measures ensued by one country constitute a violation of the sovereignty and independence of another country, and contradicts the basic principles and standards of international law, especially relating to the maintenance of international peace and security, and the prohibition of the use of force in international relations. ${ }^{(8)}$

(1) Dr. Ibrahim Darraji, the crime of aggression and the extent of international legal responsibility for it, first edition, AL-Halabi Legal Publications, Beirut, 2005, p.

(2) Dr. Ibrahim Darajy, Ibid, page 283.

(3) Dr. Ibrahim Al-Anani, International Security System, Journal of Legal and Economic Sciences, Ain Shams University, 1992 , p. 214.

(4) Dr. Ali Ibrahim, Compulsion in International Treaties, Journal of Legal and Economic Sciences, Faculty of Law, Ain Shams University, 1994, p. 100 and beyond.

(5) Dr. Abdul Karim Alwan, Mediator in Public International Law, Dar Al Thaqafa Library for Publishing and Distribution, Amman, 1997, p. 14.

(6) Dr. Mahmoud Hosni, ibid, page four.

(7) Dr. Imad Habib, Ibid, p. 176.

(8) Dr. Imad Habib, Ibid, p. 177. 
However, could be considered a unilateral economic sanctions - taken outside the framework of the international organization - legitimate and legal, and if it can be placed from the point of view of international law, "counter and punitive sanctions."

punitive measures are: They are the punitive measures used by a country against another, have harmed its legal rights and interests, and so that these measures shall include economic embargoes, boycotts, blockades, and other similar measures, with the need to adhere to the principle of moderation when exercising such measures.(1)

Countermeasures: They are the restrictions imposed by a country against another, in response to the restrictions imposed by the latter, in order to cease them; therefore the purpose of these measures is to restore the principle of dealing violated by the actions of the concerned country with these measures. Thus, counter and punitive measures are legal or coercive economic measures or procedures that can be applied by any country through international relations. (2)

Therefore, International Law Commission of the United Nations has laid down rules of international responsibility for reprisals against illegal international action, and has emphasized that the action of a country- that is taking unilateral economic sanctions - becomes legitimate, whenever this action (or sanction) is in response or A countermeasures in accordance with the rules of international law, as a result of the wrongful action of the Sanctioned Countries.(3)

Thus, the commission has legalized recourse to unilateral economic sanctions and legitimized them when the concerned country violates its international obligations towards the country imposing sanctions, and upon this, the legitimacy of these sanctions is based on the fact that they were imposed and considered as a counter to illegal actions.(4)

For example, we cite an instance relating to arbitration. If an arbitration award was issued in favor of one country against another, and you were unable to obtain its right and execute the award, this country shall not be able to take and impose unilateral economic sanctions, against this country, to force it to execute its obligation, Shall these sanctions not be in response to and counter to the country violation of its obligation and denial of the arbitration award?

On the other hand, if the rules of international law prohibit the use of armed force to execute the rights of countries, this does not apply to unilateral economic sanctions in the event that they constitute a counter action to illegal action and act that harms a country, in order to coerce the violating country to act according to its obligations. (5)

Nevertheless, the International Law Commission has laid down a set of restrictions on the application of such sanctions, as they shall not be developed to excessive political and economic coercion, which threatens the territorial integrity and political independence of the country committing the illegal action, in addition to restrictions related to human rights, These sanctions shall also be commensurate with the action taken to counter it, so that they are not arbitrary in their application.(6)

We conclude from the above, that unilateral economic sanctions may be legitimate if they are in response to an illegal act issued by the concerned country, which violates its international obligations and has acted illegally.

nevertheless -such sanctions shall not be applied broadly, even if they are a form of counter act and an execution of a right, especially in the absence of a specific authority to determine the nature of the illegal act that justifies the carrying out unilateral sanctions, therefore, this shall allow the every country to act according to its discretion, it may consider a specific act illegal even though it does not violate an international obligation, and justifies for itself the imposition of unilateral sanctions, and this constitutes a risk that may involve turning into reprisal action against the concerned country.

Therefore, it is favorable to recourse to the international community and the international organization, to issue a decision to impose such sanctions, and to apply them, unilaterally, exclusively and exceptionally.

\section{Second topic:}

\subsection{Types of unilateral economic sanctions}

Unilateral economic sanctions usually carry any character other than military ones, as they may include economic embargoes, economic boycotts, blockades and seizures of property, restricting the activity of foreigners with the nationals of the target country through measures and restricting the trade of the target country, as well as other similar measures. Such sanctions may amount to unilateral economic intervention.

Therefore, in the following sections, the types and forms of unilateral economic sanctions are examined according to the following:

(1) Dr. Imad Habib, Ibid, p. 171.

(2) Dr. Imad Habib, Ibid, pp. 172-173.

(3) See the Article / 22 / and Articles / 49-54 / of the Rules of Country Responsibility for illegal international action that were issued by the International Law Commission at its session / 53 / for the year 2001, which is available in the annual book of the Committee.

(4) Dr. Al-Khairkashi, Execution of International Court Judgments through Provision and Fact, First Edition, University Foundation for Publishing and Distribution, 2000, p. 245.

(5) Dr. Ibrahim Darajy, Ibid, P 425.

(6) Dr. Al-Khairkashi, Ibid, P247. 


\subsubsection{The first branch: Boycott, Blockade and Embargo}

In this section, the forms of unilateral sanctions: boycott, blockade and seizure, and according to that they do not differ from international economic sanctions in general. According to the following:

\subsubsection{First: The economic boycott}

The economic boycott, as Unilateral economic sanction, means that there is a country which cease its economic, material and financial relations with another country or its affiliates in order to put pressure on it and achieve its desired purposes.

A school of jurisprudence defined the economic boycott as (a practice of pressure by a country (whether by its government or its people) against another in order to isolate it without violence and compelling it to comply with international applicable rules according to the discretion of the authority that imposes this boycott) (1).

Another school defines the economic boycott as (a joint action against person or company or country through organized plans in order for the intended and nonviolent isolation, as non-acceptance expression of (or organized objection) of the actions of the target authority and putting the pressure on this authority in order to cease its unacceptable actions (2)

As it is defined: (That it suspends economic and commercial transactions and relations with a country or boycott the creation of production factors on its territory). (3)

This was underlined by others: (The economic boycott is: A set of measures to stop importing a certain type of goods, or cease financial relations, transportation, or other relations with the concerned country, adding to the possibility of boycotting goods of this country in addition to ships and planes that carry its flag).(4)

Therefore, it can be said that the boycott as an international economic sanction does not differ from it as a unilateral economic sanction, except in terms of the authority that imposes it, as it is imposed by a country unilaterally.

The boycott aims to cause economic crises for the target authority to put a pressure in order to tumble the foreign trade of the target country and disrupt its financial relations to influence on the policy of the target country. (5)

The boycott comprise many measures and acts as prohibition of import and export; their quotas; permit systems; methods of financial control over foreign exchange; external balances; navigational systems(6) . If a country suffers from economic boycott, it experiences extremely negative consequences that can be treated easily.

It should be pointed out that the economic boycott as an international sanction is imposed on aggressor country in accordance with $\mathrm{UN}$ resolution as set forth in article 41 of Charter. This does not give rise to any legal issues as all have agreed on legitimacy of imposing this sanction with consideration that United Nations is responsible for maintaining international peace and security, but the dispute is provoked by imposing the economic boycott in accordance with individual decisions depending on their international relation without resource to United Nations(7).

The scholars of international law views that imposing a boycott is inherent and legitimate right of the country; this is when is meant to put economic pressure on a country as a result of its aggressive acts and as a substitute for war acts; where, the "banned" boycott is, according to this view, this that imposed by the a country with an aim to force other countries to follow specific policies in favor that country. Therefore, this boycott is banned if it is not imposed to respond to an illegitimate act by target state. $\left({ }^{8}\right)$

On the other hand, other scholars believe that imposing economic boycott, in peacetime without a resolution issued by United Nation may threaten the cordial relations among countries, which in turn affects on the international peace and security.

Instances of imposing economic boycott individually by a country are many, including but not limited to: The European Community States impose an economic boycott on Serbia on 16 Av/August, 1991 before issuance of security council resolution no.757 on 30 Iyar/May 1922. Those sanctions include the conversion of funds by European community of Yugoslavia into economic assistance for Slovenia and Croatia in addition to cutting the assistance provided for Yugoslavia by international Financial Institutions. The scope of these sanctions is expanded, on 8 November 1991, to include suspension of financial assistance for Yugoslavia; rejection of its imports; suspension of Trade Preferences System. (9)

(1) Dr. Yasser Al-Howsh, ibid, page180

(2) Dr. Mahmoud Hassan Hosni, International Economic Sanctions and the Western World, Center for Political and Strategic Studies, AlAhram, Cairo, 1999, p5

(3) Dr. Muhammad Gamal Mazloum, Economic Wars in the twenty-first Century, Center for Political and Strategic Studies, Cairo, 2002, p. 8.

(4) Dr. Imad Habib, Ibid, p. 169.

(5) Dr. Ibrahim Darajy, the aggression and the extent of its international legal responsibility, Ibid, page 615

(6) Dr. Ibrahim Darajy, Ibid, P.616

(7) Dr. Ibrahim Darajy, Ibid, page 622

(8) . Ibrahim Darajy, Ibid, P.622 \& Dr. Yasser Al-Howsh, ibid, page 181

(9) Dr. Ibrahim Darajy, Ibid, page 622 
Also, the economic boycott by Arab countries in face of Israel pursuant to league council resolution dated 2/12/1945 which enhanced by issuance of Uniform Code to boycott Israel based upon the council resolution no.849 on 11/12/1954. The Arab countries have divided its boycott to Israel into three levels:

1. The first one: Prevent the direct contact between Arab countries and Israel.

2. The second one: Not to deal with Israel either directly or through a third party intermediary.

3. The last one: Imposing penalties on companies dealing with Israel and placing it on blacklists where is banned for dealing with any Arab country. (1)

Also, USA boycott to Bologna on 23 December, 1981 because of the use of force by the Polish forces to suppress the movement of solidarity, whose leaders were imprisoned,(2) and the United States of America's boycott to Iran between 1979 and 1980, which the States of the European Common Market and Japan have subsequently joined. This was due to detention of a number of diplomatic and consular employees in the US embassy in Tehran. (3)

\subsubsection{Second: Economic Embargo:}

The traditional definition of "Embargo" is to stop foreign ships and cargos at ports with an aim to put pressure on countries' own ships. (4)

Embargo, in this sense, is a form of retribution that is limited on detaining ships under the flags of states in violation to force it to correct the mistakes it committed.(5)

Since the end of the nineteenth century, the concept of Embargo has evolved; has taken many forms , and also it implies two meanings- one very broad and the other is less broad- concerning exports of some States, with reference that the broader meaning include also imports.(6)

The economic Embargo can be defined as (Unilateral economic sanction); therefore, it can be also defined as(the countrygovernment imposes embargo on a trade in general, or on one or more of its different aspects or the target states.) (7)

He also defined it as: (A behavior that the country pursue in a general or it prevent one or more in specific of various trade aspects against the targeted country, he adds that this behavior is imposed by the countries and it is originally allowed as it is related to the discretionary competence of the country.)(8)

The United States of America is considered the most frequent country using this embargo in its international relations, as studies suggests that the United States has used this sanction in over a hundred case, some of which for example is the embargo against the Soviet Union in 29 December of the year 1979.

The United States embargo against the Soviet Union was in response to the Soviet Union's invasion of Afghanistan in which Carter has released three embargoes the first was on grain, the second on micro technologies and the third was on Phosphates.(9)

As well as the embargo against China in June of the year 1989.

Which was following the events of the Beijing Spring, after committing the massacre in the Tiananmen Square in Beijing, President George Bush Sr has decided to impose an embargo against China that included the suspension of all weaponry sales and all military contacts with China Whereas this suspension extends to include a total of contracts amounting to 600 million USD from general contracts and 100 million USD from private commercial sales (weapons, three telecommunications satellites, navigational equipment).(10)

Besides that, the embargo imposed by Britain and was later adopted by the United Nations against Rhodesia should also be taken into consideration, as well as the embargo imposed by Arab countries against Israel after the Aggression in the year 1967, and the reduction in oil exports to countries that support Israel in 1973.(11)

It can be said that there's a difference between economic embargo and economic boycott in terms of comprehensiveness and sanctions that each of them include, as the embargo is limited to (at its narrowest conception) merely prohibiting the export of a specific good or goods to the targeted countries as per this sanction.

(1) Dr. Muhammad Jamal Mazloum, Ibid, P.9

(2) Dr. Ibrahim Darajy, Ibid, page 617.

(3) Dr. Abdul Karim Alwan, Al-waist feh Al-Qanon Al-dawli, Ibid, P.223.

(4) Dr. Imad Habib, Ibid, p. 169.

(5) Dr. Ibrahim Darajy, Ibid, page 613

(6) Dr. Ibrahim Darajy, Ibid, page 613. Therefore, we can distinguish between two types of Embargo with respect to its scope and coverage where it could be either general and inclusive or specific and defined. The general and inclusive Embargo: Includes banning the traffic at watercourses, or a flight ban from and to the concerned country of embargo. It is clear that the consequences of such embargo are serious. For the partial or specific embargo, they are only concerned with certain goods and materials that are prohibited from being exported to the target State, while trade continues to exist normally for the rest of the goods not covered by the embargo.

Dr. Ibrahim Darajy, Ibid, page 613

(7) Dr. Mahmoud Hassan Hosni, ibid, page 5

Dr. Muhammad Jamal Mazloum referred to the economic embargoes as (the prevention of sending exports to one or several countries, which does not only includes the products and Military materials but could expand to include all the products that country might need), ibid, page 7 .

(8) Dr. Yasser Al-Howsh, ibid, page 179.

(9) Dr. Ibrahim Darajy, Ibid, page 612.

(10) Dr. Ibrahim Darajy, Ibid, page 612

(11) Dr. Yasser Al-Howsh, ibid, page 179 -180. 
Meanwhile the boycott concept expand to include prohibiting the export and import simultaneously, moreover it includes the ability to impose other financial and economic sanctions which means that the concept of embargo is only a type of sanctions measures ${ }^{(1)}$, therefore the differences between them could be mainly confined to the boycott being more comprehensive in comparison to the embargo.

\subsubsection{Third: Economic blockade:}

The blockade as a form of international economic sanctions is defined above as: The prevention of the entry and exit of ships from and to the shores of a country with the intention of denying it the connection with other countries by the sea. (2)

Thus, naval blockade includes closing the port area or the coasts by military force to prevent the entry and exit of ships whether they are warships or commercial ships, as well as preventing the entry or exit of aircraft, and the prevention of any kind of aid or any movement to and from the part of the besieged, and prevent approaching the coast blocked. (3)

This is also apply to the blockade as a one sided sanction, which is considered an effective method for a country to pressure other countries due to the great importance that maritime trade hold to countries.

Therefore, the prevailing and correct view in jurisprudence has been that the naval and land blockades are considered hostile acts if imposed by a country unilaterally or by only one side. (4)

As an example of the unilateral economic blockade, we refer to the comprehensive blockade - land, sea, and air - imposed by Israel against the Palestinian people during the Al-Aqsa Intifada of the year 2000, Within the framework of the Israeli blockade policy for the West Bank and Gaza, the Israeli authorities take many measures such as closing the boarders, preventing the passage of goods and individuals, prohibiting Palestinian merchants from importing goods that have agents in Israel, imposing the use of raw materials and production requirements from Israel on industries and economic activities in the West Bank and Gaza (such as building materials), confiscation of agricultural and non-agricultural lands and house demolitions, restrictions on the use of the Rafah airport by the Palestinian Authority, restrictions on trying to establish an advanced commercial port in Gaza, imposing the Israeli currency (Shekel).(5)

\subsubsection{Second section}

\subsubsection{Unilateral economic intervention}

World countries, especially third world countries, seek to expand the concept of intervention to include, in addition to armed military intervention, economic intervention that is carried out through pressures and threats, and refusal to provide aid to other forms of intervention practiced by countries in the level of their international relationship. Therefore, it is necessary to clarify what is meant by this intervention, and to clarify its legitimacy or not in light of the condemnation that it is exposed to by the General Assembly, Economic, and Social Council of the United Nations.

\section{First: Definition of unilateral economic intervention and its elements:}

Perhaps one of the most difficult tasks that jurists have intercepted in the field of international law is to define a precise definition of what is meant by economic intervention at the international level.

Some has defined unilateral economic intervention as: It is (Exerting pressure in which economic instruments are used by one of the countries against another or a group of sovereign countries, with the intention of imposing an foreign will on them without that having a legal document for it).(6)

Or it is (the pressure in which economic means are used to influence the internal affairs of other countries, or the means by which it is intended to attack the internal economic elements of the targeted country).(7)

The Colombian scholar "Abiza" point out that the economic intervention is the process of the country emergence by using its economic power through intervention in anothercountry matters; Abiza also adds that this intervention can be done by means of using physical power or just threaten to do so.(8)

As from Professor Charles Rousseau's perspective, he views the economic intervention as (An act done by a country under which it can intervene in anothercountry internal and external affairs trying to impose its administration on it by means of economic pressure and forcing it to execute or not to execute some affairs.)(9)

(1) Dr. Ibrahim Darajy, Ibid, page 611.

(2) Dr. Ibrahim Darajy, Ibid, page 340.

Dr. Muhammad Jamal Mazloum defined naval blockade as, foreign ships surrounding the country's ports with the intention of preventing its ships from leaving the port and preventing other ships from reaching it, whether these ships are hostile or neutral, ibid, page 7.

(3) Dr. Ibrahim Darajy, Ibid, page 340.

(4) Dr. Ibrahim Darajy, Ibid, page 344.

(5) Dr.Ibrahim Nawara, Blockade and Development, Impact of sanctions on development in Libya and Sudan, Center for Political and Strategic Studies, Cairo, 1997, page 11. The blockade imposed by the Israeli army on the Palestinian lands in the year 2000 has resulted in tremendous impacts on the Palestinian economic, as the losses incurred by the Palestinians due to the blockade from October 2000 to June 2001 ranged between 1.8 billion USD and 2.5 billion USD, and the unemployment rate was about $27 \%$ in the first quarter of 2001 .

(6) Dr. Mustafa Salamah Husayn, Ambivalence of Treatment in Public International Law, Dar Alnahda Alarabia, Cairo, 1987, page 46.

(7) Dr. Yasser Al-Howsh, ibid, page 174

(8) Pokra Idris, Mbdaa’ Al-tadakhol feh Al-qanon Al-dawli Al-mo'aser, P.214.

(9) Dr. () Pokra Idris, Mbdaa' Al-tadakhol feh Al-qanon Al-dawli Al-mo'aser, P.214-215. 
The international jurisprudence seem not to have a clear view of the economic intervention, may be, due to its focus on the issues of armed intervention as the primary concern of international jurisprudence is to maintain the international peace and security. Despite that only few scholars address the issue of economic intervention, the elements of this intervention are quiet clear. (1)

Even that the elements of the economic intervention can be deduced based on its previous definitions, but the economic intervention, from other side, require a material act through which it could be quiet clear. In addition, this act can be represented in pressure, which is considered as a conduct by the intervening country that can truly threaten the existence of sovereign state. (2) by economic means as breaking-off commercial relationship or threaten to do so or withholding assistance provision or imposing high custom duties on concerned country exports or Freezing or confiscation of the non-financial assets of the target State... (3) and what so ever of this interventionist practices which in turn can affect the concerned country economic elements by means of its economic intervention.

Another aspect of jurisprudence states that using this economic means (the unilateral ones) and the like with the aim of placing pressure over other states does not only constitute a form of economic intervention, but also is a Violation of Article Four of UN charter as the mentioned embargo in Article 4(2) is not only limited to the use of armed or military force, but it is about all forms of pressures and threats; for instance, the economic pressure. This is when certain danger levels have been reached because the mentioned embargo in the aforementioned Article is general and absolute.

The concept of Power or Force here as per the Article 4(2) is expanded to comprise, beside the armed force, other forms as threats; political and economic pressure. In other words, this concept, as per the Article 4(2), does not only refer to armed force, but to any phenomena inferred Force especially economic coercion. (4)

The Charter includes fundamental guarantee to achieve security for each state. This guarantee is represented in respecting the principle or the rule prohibiting the use of force or threatening by so in respect to international relationships. The first aspect to be noted that the mentioned embargo is not limited to armed force as in conventional traditional law, but extended to comprise any use of force; even threating lies within the scope of this prohibition.

On the other hand, the unilateral economic intervention usually targets affecting the external or internal affairs or both of sovereign state. As for the internal affairs and despite all the ambiguity most of authors notice surrounds the issues of determining the matters relevant to the internal matters, but it is still can be determined as follows:

A. The political, economic, social and constitutional forms of the country.

B. Economic, financial, administrative and social matters.

C. Language, religious beliefs and cultural entity of the country.

As for foreign affairs, they are those matters related to the independence of the country in managing its foreign relations and establishing diplomatic, economic and commercial relations with other countries. (5)

So that exposure to such issues and their violation is considered Unlawful Acts, because the country has the right to choose its appropriate political and social system, and to issue the necessary legislation to regulate its economic, financial and administrative affairs, and to manage its foreign relations completely freely and without any foreign intervention or pressure by any State.(6)

Finally, the aim of this intervention is the desire of the interveningcountry to maintain the existing conditions as they are in the concerned country, as required by the country circumstances and the interests of the state. (7) (As an attempt to protect the existing system and prevent the political and economic system in the target country from changing the economic intervention, or protecting Nationals of the intervening country and their interests or protection together).

Thecountry may aim behind its economic intervention, to change the conditions in this country, because the conditions in it do not proportionate with its vital and strategic interests and severe a threat to it (8).

Economic pressures have often been used on the revolutionary changes that occur in the countries of the third world, such as taking measures to recover oil wealth and progressive reforms within the country, and that the hinting of these pressures is aimed at intimidating the country and threatening it to force it to reconsider its actions or thwart the measures it has taken (such as the economic blockade) That the United States imposed on Cuba and

(1) Dr. Yasser Al-Howsh, ibid, page 174

(2) Dr. Mahmoud Mashrahah, Al-Wajeez in Public International Law, Directorate of Books and University Publications, University of Aleppo, 1994, p.185.

(3) Ibrahim Nawar, ibid, P.7

(4) Dr. Abdul Salam Saleh Arafa, Al Monazamat Al Duwaliya wa Al'iiqlimia, Al-Dar Al-Jamahiria for Publishing, Distribution and Advertising, Libya, 1999, P.143 \& Pokra Idris, Ibid, p. 123

(5) Dr. Abdul Karim Alwan, Al-waist feh Al-Qanon Al-dawli, first part, Ibid, P.128

(6) Dr. Pokra Idris, Ibid, p. 221.

(7) Dr. Muhammad Ali al-Qawzi, International Relations in Modern and Contemporary History, Dar al-Nahda al-Arabiya, Beirut, Lebanon, 2002, p. 50.

(8) Dr. Muhammad Ali al-Qawzi, Ibid, P.52 
on Iran "after the revolution" and the economic boycott imposed by France on the Algerian vineyards when Algeria nationalized hydrocarbons). ${ }^{(1)}$

As a summary of the foregoing, it can be said that the elements of unilateral economic intervention are manifested by pressure through the use of economic means affecting internal or external affairs, or both, of a sovereign state, with the aim of achieving specific effects, either in order to compel the concerned country to keep the current conditions as they are It must be changed or adapted to the interests of the interventionist state.

It should be noted that a number of jurists distinguish between lawful and unlawful economic intervention such as Dr. "Gerhard Van" and Professor "Charles Rousseau", while no such distinction has been endorsed by another side of international legal jurisprudence, such as Dr. "Abdul Aziz Sarhan," who states That: ((It is difficult to find an accurate standard for the distinction between lawful and unlawful economic intervention, because leaving matters to countries will lead to misjudgment, and will work according to their own and personal interests, and therefore all states must resolve their disputes peacefully and comply with the provisions of international law).(2)

On the other hand, quite a few contemporary jurists(3)On the other hand, quite a few contemporary jurists () unanimously consider unilateral economic intervention as a prohibited and unlawful act because it constitutes an attack on the sovereignty and independence of the state, and it is a violation of the obligation of states that impose respect for each other's rights.

It is worth noting that the economic intervention imposed by an international organization, even if it is considered - as a general origin - a legitimate sanction, unless this party arbitrarily applied this sanction, so that its results exceed what is intended by this sanction, by preventing the people of the concerned country from exercising their political freedom Or undermining economic foundations, or influencing human rights-related values, here the sanction is unlawful. (4)

Despite this emphasize of the illegality of theintervention, the modern jurisprudence tends to accept some unilateral economic intervention cases besides considering such cases as legitimate.

As the Oppenheim considered that (economic intervention which not violates country's sovereignty and its independence political is legitimate) For instance, according to his point of view "the country violates peacetime, economic intervention to protect the nationals abroad and their possessions and intervention to engage the country to abide by international law. (5)

Notwithstanding, the acceptance of these cases except the first, considered to be a violation for country's sovereignty and its political independence, so the acceptance means the support of colonial domination era and spheres of influence ideology.

Others are legalizing economic intervention, if it was in accordance with international obligations, as provided in The Charter of the United Nations. (6)

In view of the above, It may be said that, various economic means used by counties to force other countries to adopt certain policies or changing a certain attitude, considered to be aviolation of the provisions of international law, specifically those relating to ban restoring force or threatening to use besides the principle of peaceful settlement of disputes and Peoples' right to self-determination.

As the economic independence, The right of country and peoples to control their natural wealth, prohibition of any form economic intervention of the country and using force and all forms of pressure in international economic and trade relations(7) are deemed as one of the essential principles of Contemporary international law.

\section{Second: Condemning unilateral economic intervention of United Nations resolutions.}

It is possible to conclude economic intervention condemning in a set of resolutions adopted by the Assembly and UN Economic and Social Council as follows:

The General Assembly has embarked to issue a number of resolutions regarding promoting economic intervention condemning, prohibition of using coercive actions and economic pressure with the objective of ensuring international peace and security, developing cordial relations and improving peaceful coexistence among countries in a context of mutual respect and sovereign equality, and among the most significant of these resolutions:

- Resolution/ 2131/ issuing during 20th season on 21 December 1965, this resolution setting in the first paragraph as follows: «... But also all forms of interventions or threatening against personality of the countryor its political, economic and cultural elements » and the second paragraph provided for the duty of country to refrain from «... Applying or promoting economic or political actions or any other action to

(1) Dr. Pokra Idris, ibid, page 219

(2) Dr. Pokra Idris, ibid, page 224.

(3) Among them, the jurist Sharpanti, who says: (The country cannot exert pressure on another state, to compel it to act according to its whims, and that all military, economic and diplomatic pressures exerted by acountry against another one, are illegal), Dr. Pokra Idris, ibid, page 227.

(4) Dr. Yasser Al-Howsh, ibid, page 249.

(5) Dr. Pokra Idris, ibid, page 228.

(6) Dr. Pokra Idris, ibid, page 229.

(7) Dr. Pokra Idris, ibid, page 380. 
be taken to force another country to compromise on its sovereignty rights or get benefits of any kind from them».

As noted in the sixth paragraph of the resolution: «For every country the right to refuse the intervention of any other country in choosing its political, economic, social and cultural system». (1)

- Resolution no. 2653 at its twenty-five session on 24 October 1970, as that resolution exposed the concept of economic intervention. As it has the same paragraphs contained in Resolution no. 2131 and the principle of Co-operation among States in accordance with the Charter, as the third paragraph invites all states to "conduct of their international relations in the economic, social, and technical and trade fields in accordance with the sovereign equality and non-intervention".

The sixth paragraph of the clause concerning the principle of sovereign equality among States stated "The sovereign and inalienable right of a country freely to determine its own political, economic, cultural and social system".

- Resolution no.3201 at its sixth exceptional session on 1 May 1974 concerning declaration on the establishment of new international economic order. As the fourth paragraph includes a set of principles as basic for the new international economic order, one thereof is "Every country has the sovereign right to choose its economic and social system as in accordance with the will of its people, without outside intervention, coercion or threat in any form whatsoever".

As the resolution states at the same paragraph and fifth principle that "No country accepts any economic, political, or other pressure, preventing it from complete and freely practice of such non-derogable principle. (2)

- Resolution no. 3281 at its twenty-ninth session on 12 December 1974 concerning rights and duties of states, as the first clause thereof states "No country may use or encourage the use of economic, political or any other type of measures to coerce another one in order to obtain from it the subordination of the exercise of its sovereign rights".(3).

- Recalling also its resolutions 31/91 of 14 December 1976 on non-intervention in the internal affairs of States. That resolution asserts the sovereign and inalienable right of a country freely to determine its own economic, cultural and social system without outside intervention. The resolution refers to the forms of intervention invading states such as refusal of assistance, threat for refusal of assistance, and subversion to destroy regimes and governments that towards self-government, economic independence, and to exercise permanent sovereignty over its natural resources.(4)

- ECOSOC regulation condemned the economic intervention in 1973, as the regulation states the following: "any practice used by country against another one to prejudice its inalienable right, to exercise permanent sovereignty over its natural resources, to exert pressure to get whatever benefits and any text of legislation provided for the same. That act forms a clear violation of UN Charter and contrary to the principle authorized by United Nations General Assembly in resolution no. 2652 and 3016 (at twenty-seven session) and maintenance of such forming a threat for the international peace and security". (5)

- ECOSOC regulation no 1965 of 25 July 1975 asserted on freedom of states to practice a permanent sovereignty over their natural resources, as regulation stipulates the following: "United Nations firmly asserts on states' rights to exercise sovereignty over its natural resources, wealth, and all economic activities".

- Also a resolution no. 165 of 25 July 1975 concerning the economic procedures taken for exerting political or economic pressure on the developing countries, and its resolution no 22/55 named (end the coercive measures as means of the economic and political forcing).(6)

- Perhaps the most prominent decision is the UN General Assembly Resolution No. / 176 / Dated 26/3/2009 which was released on the agenda of the General Assembly and entitled (Human Rights and Unilateral Coercive Measures). In it, the Assembly mentioned the necessity of not taking any unilateral action or measure that does not conform to international law and principles governing relations between countries, and it considered that such sanctions or measures threaten international relations and constitute a violation of the sovereignty of countries.(7)

\section{CONCLUSION}

Through this research we reach the following results:

1. The characteristics of unilateral economic sanctions are that they are imposed by a country unilaterally

(1)Dr. Pokra Idris, ibid, P 263.

(2) Dr. Yasser Abu Shabana, The New International system, Dar Al-Salam for Printing and Publishing, Cairo, 1998. P. 23

(3) Dr. Yasser Abu Shabana, Ibid, p. 24

(4) Dr. Imad Habib, Ibid, p.177 to...

(5) Dr. Pokra Idris, Ibid, p. 383

(6) Dr. Khawla Yusuf, Ibid, p. 143

(7) Dr. Khawla Yusuf, Ibid, p. 144 
(that is, outside the framework of the international organization), against a country in order to force it to take action or refrain from it.

2. The unilateral economic sanctions are consistent with international economic sanctions (taken by an international organization) of an economic nature, but differ from them in the body that imposes them (or the competent authority that shall sign them). Whereas the international organization is the framework of imposing international economic sanctions, whether they are imposed by the organization's bodies or countries are mandated to implement them, therefore countries shall then impose unilateral economic sanctions.

3. Unilateral economic sanctions represent a clear violation of the principles of international law and its peremptory norms, especially those rules that prohibit members of the international community from resorting to force, or merely threatening to use it on the level of international mutual relations among them, as well as a violation of the rules that affirm the sovereignty of countries and the inadmissibility of intervention in their internal affairs or in the area reserved for those countries.

In addition, unilateral sanctions that affect the other international principles and rules contained in the preamble and provisions to the Charter, and international action have been established with a view to achieving international security and stability in their broadest sense, Such as the principle related to the peaceful settlement of international disputes in a manner in which international peace and security, as well as States vulnerable, and principles relating to the development of friendly relations and the development of peaceful coexistence between countries

4. Unilateral economic sanctions may be legitimate if they are in response to an illegal act issued by the concerned country, which violates its international obligations and has acted illegally.

From the above, we conclude that:

It is necessary to work to expand the rule of the embargo of the use of force at the level of international relations in order to maintain international peace and security, by preventing states from using unarmed force by resorting to unilateral economic pressures and sanctions.

Therefore, these sanctions are an expression of the politics of power and domination in international relations, which is inconsistent with the provisions and principles of contemporary international law and the decisions of international legitimacy.

nevertheless such unilateral economic sanctions shall not be applied broadly, even if they are a form of counter act and an execution of a right, especially in the absence of a specific authority to determine the nature of the illegal act that justifies the carrying out unilateral sanctions, therefore, this shall allow the every country to act according to its discretion, it may consider a specific act illegal even though it does not violate an international obligation, and justifies for itself the imposition of unilateral sanctions, and this constitutes a risk that may involve turning into reprisal action against the concerned country.

Therefore, it is favorable to recourse to the international community and the international organization, to issue a decision to impose such sanctions, and to apply them, unilaterally, exclusively and exceptionally.

\section{ACKNOWLEDGEMENTS}

The author would like to thank Middle East University Jordan for its support of this research.

\section{Works cited list:}

1. Dr. Ibrahim Al-Anani, Public International Law, Dar Al-Fikr Al-Arabi, Cairo, 1984

2. Dr. Ibrahim Al-Anani, International Security System, Journal of Legal and Economic Sciences, Ain Shams University, 1992.

3. Dr. Al-Khairkashi, Execution of International Court Judgments through Provision and Fact, First Edition, University Foundation for Publishing and Distribution, 2000.

4. Dr.Ibrahim Nawara, Blockade and Development, Impact of sanctions on development in Libya and Sudan, Center for Political and Strategic Studies, Cairo.

5. Dr. Ibrahim Nowar, Blockade and Development, Al-Ahram Center for Political and Strategic Studies, Cairo, 1997.

6. Dr. Ibrahim Darraji, the crime of aggression and the extent of international legal responsibility for it, first edition, AL-Halabi Legal Publications, Beirut, 2005

7. Dr. Pokra Idris, Mbdaa' Al-tadakhol feh Al-qanon Al-dawli Al-mo'aser, Al Moasasa Al Watania lil Kitab, Algeria, 1990

8. Dr. Khawla Yusuf, International economic sanctions adopted by the Security Council, Al-Halabi Human Rights Publications, Beirut, 2012.

9. Dr. Abdul Salam Saleh Arafa, Al Monazamat Al Duwaliya WA Al'iiqlimia, Al-Dar Al-Jamahiria for Publishing, Distribution and Advertising, Libya, 1999.

10. Dr. Abdul-Aziz Sarhan, The New International Order and International Legitimacy and Its Impact on the Arab 
World, A Study in the Light of the General Theory of International Organizations, Cairo, Dar Al-Nahda AlArabia, 1993.

11. Dr. Abdul Salam Saleh Arafa, Al Monazamat Al Duwaliya wa Al'iiqlimia, Al-Dar Al-Jamahiria lil Nashr, Libya, 1999.

12. Dr. Abdul Qadir Al-Qahwaji, Al-Qanoon Al-Janaie, Manshurat Alhalabi Alhuquqia, Beirut, Lebanon, 2001.

13. Dr. Abdul Karim Alwan, Mediator in Public International Law, Dar Al Thaqafa Library for Publishing and Distribution, Amman, 1997.

14. Dr. Abdullah Muhammad Al-Ayoun, Collective Security System in the Modern International Organization, Dar Al-Bashir and Distribution, Amman, Jordan, 1985.

15. Dr. Abdel Wahad El Far, The Nature of the International Economic Base under the Existing International System, Dar al-Nahdah al-Arabiyah, 1985.

16. Dr. Ali Ibrahim, Compulsion in International Treaties, Journal of Legal and Economic Sciences, Faculty of Law, Ain Shams University, 1994.

17. Dr. Imad Habib, International Economic Law, Nineveh Studies, Damascus, 2001.

18. Dr. Muhammad Al-Saeed Al-Dakkak, The International Order, al-Dar al-Jamieia lil-Tibaah wa-al-Nashr, Alexandria, n.d.

19. Dr. Muhammad Al-Majzoub, Public International Law, Al-Halabi Human Rights Publications, Beirut, Lebanon, 2002.

20. Dr. Mohamed Bedjaoui, for a New International Economic Order, UNESCO and the National Publishing and Distribution Company, Algeria, 1980, pp. 198-199.

21. Dr. Muhammad Gamal Mazloum, Economic Wars in the Eleventh Century, Center for Political and Strategic Studies, Cairo, 2002.

22. Dr. Mohammed Talaat al-Ghunaimi, Mediator in the Peace Law, Munsha'at Al Maearif, Alexandria.

23. Dr. Muhammad Ali al-Qawzi, International Relations in Modern and Contemporary History, Dar al-Nahda al-Arabiya, Beirut, Lebanon, 2002.

24. Dr. Mohamed Mostafa Younes, The General Theory of Non-Intervention in County Affairs, a Doctrinal and Applied Study in light of the Principles of Contemporary International Law, Doctoral thesis, Cairo University, 1985.

25. Dr. Mahmoud Hassan Hosni, International Economic Sanctions and the Western World, Center for Political and Strategic Studies, Al-Ahram, Cairo, 1999.

26. Dr. Mahmoud Mashrahah, Al-Wajeez in Public International Law, Directorate of Books and University Publications, University of Aleppo, 1994.

27. Dr. Mahmoud Mashrahah, Al-Wajeez in Public International Law, Directorate of Books and University Publications, University of Aleppo, Syria, 1994.

28. Dr. Mustafa Salamah Husayn, Ambivalence of Treatment in Public International Law, Dar Alnahda Alarabia, Cairo, 1987.

29. Mary Helen Labet, Economic Struggle in International Relations, translated by Hassan Haidar, Aweidat Publications, Beirut, 1996.

30. Dr. Yasser Abu Shabana, The New International system, Dar Al-Salam for Printing and Publishing, Cairo, 1998.

31. Dr. Yasser Al-Huwaish, Principle of Non-Intervention and Global Trade Agreements, PhD thesis, Ain Shams University, Egypt, 2001.

\section{English references:}

1. Lucie spanihelova how states decide between unilateral and multilateral senctions, research published by deparment of political sience sunny, binghamtion 'ISA annual conference san diego, CA, 22-26 march

2. Robert p.Q quinn, auser's guide to economic santionsm, the heritage foundation, 1997 heritage foundation website "http//www.heritage.org/research/national security'

3. Shaw (Martin), the global state and the politics of intervention the center for the study of global governance London school of economics, 1994 discussion

4. Lauterpacht (h), the international protection of human rights, Rcadi, 1947, tome 70 